\title{
Animal Rights Theory from the Legal and Bioethical Perspectives
}

\author{
Edna Cardozo Dias \\ Faculdade FUMEC - Fundação Mineira de Cultura, Brasil \\ https://orcid.org/0000-0001-6070-5932
}

Alvaro Angelo Salles

Ph.D. Bioethics W/Gr, CFM/UP, Brasil

Recommended citation. CARDOZO DIAS, E., SALLES, AA., Animal Rights Theory from the Legal and Bioethical Perspectives, dA. Derecho Animal (Forum of Animal Law Studies) 10/3 (2019) - DOI https://doi.org/10.5565/rev/da.443

\begin{abstract}
Based on the alterations of new scientific paradigms that sustain the demand for a relationship between humans and non-human animals founded on bioethics, this paper seeks to highlight the urgency in the creation of a new legal status for animals in Brazil, and the need of relocating Animal Law as an autonomous academic discipline.
\end{abstract}

Key words: Animal Law; Environmental Law; Legal status of animals; Animal as person; Animal as thing; Bioethics; Abolitionism; Speciesism.

\section{Resumen - Teoría de los derechos de los animales desde la perspectiva bioética y jurídica}

En base a las alteraciones de nuevos paradigmas científicos que sostienen la demanda por una relación entre animales humanos y no-humanos basada en la bioética, el presente artículo busca destacar la urgencia de la creación de un nuevo estatuto jurídico para los animales en Brasil, y la necesidad de reposicionar el Derecho Animal como una disciplina autónoma.

Palabras clave: Derecho Animal; Derecho Ambiental; Estatuto jurídico de los animales; Animal como persona; Animal como cosa; Bioética; Abolicionismo; Especismo.

\section{Introduction}

Scientific revolutions bring, as a natural result, the adoption of new paradigms, which tend to influence different fields of knowledge. In the last few centuries, as a consequence of important discoveries in various areas of science, there has been a expansion in awareness that would affect the then existing perceptions in relation to the role of animals and of the interaction between humans and animals, and the relocation of the latter within the legal field.

In Brazil, a relevant change of paradigm happened in the year 2000, in the field of Animal Rights. Until that moment, the respective rules, laws and principles regulated animal protection and sought to guarantee its physical and moral integrity, as well as its dignity as a non-human animal. From that moment 
of change, however, the animal began to be considered for itself.

Of undeniable importance, nonetheless the change showed a long road to be traveled by Animal Law, which to this day does not constitute an independent branch of Law, being treated indirectly through Environmental Law. Even though laws regarding animal protection are not new, their debate hits on obstacles that need to be understood in order to be surpassed.

In the present text, based on the examination of the dynamics that lead to the emergence of new paradigms in certain moments of History, the objective is to identify the elements that demand change in the relationship pattern between humans and non-human beings, and to show that these changes need to encourage the discussions about laws regarding animal protection to be done within a broader dimension, based on bioethics and sustained by principles of autonomy and otherness.

As a result of this study, the authors hope to express the urgent need in structuring a theory of animal rights and the importance of having Animal Law designed as an autonomous discipline.

\section{The why and how of scientific revolution}

When Darwin [1809-1882] removed man from the pedestal he put himself on as king of creation, and brought to light evolutionary theories, there was no way of sustaining the old theories and dated scientific paradigms - the world had changed, and so had science. Furthermore, one can see by looking into the past that Darwin's theory of evolution could be considered as one of the first blocks in the building of an animal rights theory. Going against the mechanical paradigms that were propagated since Galileo and Bacon, and that found their peak mostly with Descartes and Newton, Darwin explained the evolution of man as the result of millions of years of natural and sexual selection. It was one scientific revolution replacing the other. The Cartesian model that was predominant for centuries - itself a substitute for the medieval scholastic thought - was being overturned.

Analyzing this change of paradigms throughout history, and keeping in mind that what is proposed at the moment is also a new theory, it is fitting to understand how and why such changes take place.

The human thought process evolves each day, with each generation, and so science evolves in a similar manner. At the same time, science (evolving every day and with each generation) creates new ways of thinking. Hence, as a wheel that doesn't stop turning, through time new scientific paradigms generate new theories that replace previous ones. This phenomena, however, doesn't happen suddenly, at the moment a new theory appears. The foundations are gradually created, having as background the motion of social dynamics.

The new, as it is taught by Psychology, can be frightening, and consequently there will be a resistance against its introduction in our lives. The new can mean a demand for different stances, an escape from the comfort zone, sometimes even an expansion of awareness. Similarly, a new scientific paradigm can encounter resistance, which brings us to question how such paradigm will be finally established.

Generally, one can say that to be established, a new paradigm needs the acknowledgement of a significant number of members of the scientific community. A group of scientists that share paradigms correspond, according to physicist Thomas S. Kuhn, ${ }^{1}$ to a scientific community and, inversely, as he clarifies, a paradigm is what the members of that community share. Science, for Kuhn, is a conjunction of facts, theories and methods, the scientists being the people that contributed towards the formation of such a specific constellation. Those facts, theories and methods, emerging alone or with others, would form a growing stock that constitutes the scientific knowledge and technique of a particular time. As for new discoveries, Kuhn thinks that they happen only because beliefs or procedures previously used are gradually abandoned and discarded, and are simultaneously replaced by others.

The analysis of laureate physicist Max Planck stems from another perspective. For him, "a new scientific truth does not triumph by convincing its opponents and making them see the light, but rather because its opponents eventually die, and a new generation grows up that is familiar to it". ${ }^{2}$ Whatever the manner of explaining or justifying a new scientific paradigm, the fact is that its introduction is not sudden. There are, either in the closest or furthest moment away from its emergence, factors that were conductive to such a moment, which - by the way - is particular to the processes of human change.

$\mathrm{Kuhn}^{3}$ also defends that the transition from an old paradigm to a new one - from which can appear a new tradition of common science - is not a cumulative process, an outcome of the previous paradigm's articulation. It is, above all else, a reconstruction of the field of study based on new principles. Such reconstruction, as he explains, modifies some of the more elementary theoretical generalizations from the

\footnotetext{
${ }^{1}$ KUHN, TS, A estrutura das revoluções científicas (São Paulo 2013)

2 PLANCK, M., Scientific autobiography and other papers (New York 1949) 33-34

${ }^{3}$ KUHN, TS, A estrutura das revoluções científicas, cit.
} 
old paradigm. To this transition from old to new paradigms, now incompatible amongst themselves, Kuhn calls it scientific revolution. The key point of Kuhn's theory is that a new paradigm is always preceded by a crisis. Hence, a paradigm in crisis would be the prelude to the arrival of new theories.

Everything that stops working properly, as we know, creates anomalies, whether they are within human relationships, or in the relations between humans and nature. In the case of a legal paradigm, when this is accepted by the doctrine and by the academic world, new theories are created to explain such anomalies. A theory will then be considered successful if it solves the issues left by the previous theories.

\section{Prelude for an animal rights theory}

Keeping in mind the how and the why for the emergence of new scientific paradigms, it is then necessary to analyze, from such perspective, the time period that precedes the appreciation of Environmental Law and Animal Law. Darwin's line of thinking contradicted, as seen above, the order of the CartesianNewtonian paradigm, a paradigm strongly rooted within the scientific community for centuries. As psychologist and anthropologist Roberto Crema explains, that old paradigm was founded on objectivity from an unbiased observation. "Descartes divided man in body and soul", establishing the duality in philosophy, which historically represented the radical metaphysical duality, according to Crema's analysis. ${ }^{4}$

Besides undoing the notion that man was made and finished at the time of his creation, Darwin ${ }^{5}$ sought to demonstrate that this being was not separate from nature, nor was it superior to animals. On the contrary, as he illustrated in his work, there are more similarities than differences between humans and animals, not only anatomically and physiologically, but also behaviorally when found in situations of stress and pleasure. It's from Darwin the affirmation that "there is no fundamental difference between man and higher mammals when it comes to mental faculties", ${ }^{6}$ adding that, in the case of small sized animals, their mental faculties are much bigger than one could expect.

Darwin draws attention to qualities that are found both in humans and in animals, with varying degrees. For example, some dogs and horses are grouchy, others are joyful; some animals are calm, others act more energetically; some animals show suspicion, while others show courage or shyness; the majority respond well to stimuli and do not appreciate boredom. In the case of females, it is noticeable the same motivation that exists among women when it comes to maternal affection, which Darwin exemplified with the case of young orphaned monkeys being adopted by other female monkeys. Some animals, as the scientist explains, demonstrate love for their owner, even being able to show jealousy among animals when it comes to showing affection for their owner. And so Darwin concludes: "This shows that not only do animals love, but they have the desire to be loved". 7

During Darwin's time period, before and after him, scientific discoveries were abundant, bringing more elements to the crisis scenario that preludes new paradigms. Michael Faraday [1791-1867] and James Clerk Maxwell [1831-1879] made the first steps in the research that would lead to electromagnetism, with the concept of strength being replaced by the concept of force field, as described by Capra. ${ }^{8}$ According to Crema, ${ }^{9}$ there was, in 1900, a revolution in the field of Physics when Max Planck [1858-1947] presents the quantum theory, kick-starting Quantum Mechanics, and when another physicist, Albert Einstein [18791955] introduces Modern Physics, which is relativist, atomic and quantic. In the 1930s, Werner Heisenberg [1901-1976] formulates the "principle of uncertainty", which demonstrates the impossibility of knowing the position and speed of a particle simultaneously. Therefore, science does not have the privilege of knowing everything anymore, as Goldim analyzes. ${ }^{10}$ The indeterminacy should be taken into consideration, and time would have to be accepted as a fundamental variable in each and every process, and responsible for changes. When joining time with indeterminacy, one can verify that the processes not only change, but also can modify the way they change.

At this stage, where scientific-technological progress was boiling, German theologian Fritz Jahr [1895-1953] publishes an article warning about the tendencies of scientific-technological development of that time and the near future. He proposed that humans take responsibility over animals and plants, living beings that should be equally considered. To this ethical stand in regards to other forms of life, Jahr called

\footnotetext{
${ }^{4}$ CREMA, R., Introdução à visão holística: breve relato de viagem do velho ao novo paradigma (São Paulo 1988) 29-30

${ }^{5}$ DARWIN, C., The descent of man, and selection in relation to sex (London 2004)

${ }^{6}$ Ibid. 86 (own translation)

${ }^{7}$ Ibid. 92 (own translation)

${ }^{8}$ CAPRA, F., O tao da Física (São Paulo 1983)

${ }^{9}$ CREMA, R., Introdução à visão holística: breve relato de viagem do velho ao novo paradigma, cit.

${ }^{10}$ GOLDIM, JR, Histórico da Bioética, in HCPA, 2 (2006) 86-92, in https://www.ufrgs.br/bioetica/complex.pdf [last visited 10 March 2019]
} 


\section{Bioethics.}

Bioethicists have declared Jahr as the first to use this term. His article "Bioethics: A Review of the Ethical Relationships of Humans to Animals and Plants" was published by Kosmos magazine in 1927 - a guide for nature lovers and main medium for formation and collection in natural sciences. Other constantly quoted texts by him are "Death and Animals" and "Protection for Animals and Ethics", both from 1928. Although the mentioned article by Jahr in Kosmos is considered to be a reference in the origins of bioethical writings, Hoss ${ }^{11}$ points out that, if we take the collection that joins that article and another 15 by Jahr, we'll see that, as a whole, it offers important elements for the expansion of a bioethical vision, especially when it comes to the relationships of man with other forms of life. Jahr manages to express the need for an ethical responsibility of man towards animals and plants. And this responsibility, according to him, needs to be based on love and compassion.

To create links for his basis, Jahr works with authors from different fields such as Schopenhauer in Philosophy; Schleiermacher in Theology; and Wagner in Music. The term that headlines the article, "bioethik", is a result of Jahr's proximity with texts from thinkers like Fechner, Francé and Eisler, the latter a researcher of a newly formed field, Bio-psychology. It is important to highlight the imperative formulated then by Jahr: "Respect every living being as an end in itself, and, if possible, treat it as such!". ${ }^{2}$ The importance of such imperative is underlined for representing a rupture with Kant's ethical imperative, which was anthropocentric. Going against Kant's teachings, Jahr presents a Global Bioethics that is integrative, that contemplates every living being. Jahr ratifies this stand in his following writings, when he dives into the different aspects of the relationships of man with other forms of life. Furthermore, Jahr also stimulated the inclusion of bioethical education in academia and for the general population, using newspapers and radio stations as auxiliary means.

Jahr's tonic in his writings is that care with the need of a new way of connecting man with other forms of life, a need stemmed from - as previously shown - his vision of the complex changes that the future would bring for humanity and the planet. From this comes his prestige among modern day ecologists. As Hoss ${ }^{13}$ points out in his revision of Jahr's articles, the indispensable behavioral change of man in regards to the biosphere demands paradigms about the way of being oneself and before the world. Hoss ${ }^{14}$ also points out the pertinence in Hans-Martin Sass' conclusion (a researcher, encourager and one of the editors of Jahr's works), when he affirms the character of Jahr's Bioethics as a discipline, principle and virtue. Jahr's work came to show that what matters is not the volume or language density of a piece of work. He wrote in a consistent and brief way, but, as Hoss highlights, always paved in his purpose of refreshing and widening the bioethical reflection translated in his bioethical imperative, and always having as his goal the imminent challenges of the relationship of man with other living beings.

In 1979, Hans Jonas [1903-1993] presents his theory about man's responsibility in the technological era in relation to nature's conservation. Originally exposed in "The Imperative of Responsibility: In Search of Ethics for the Technological Age", ${ }^{15}$ the theory exposes Jonas' worry regarding an ethical and respectful relationship towards all living beings, as well as the planet's preservation as a whole. Taking into account that the most modern technology available during his time was being used for purposes that did not harmonize with the ideals of peace and freedom, Jonas and other thinkers noticed that the improper use of reason could be responsible for the tragic and systematic destruction of life on Earth. And so, Jonas' worry doesn't stay confined to his present - he defends an ethical principle of protection of the beings that would come into existence, so that humanity's future could be safeguarded. Within a scenario of inconsequential misuse of technology by man, Jonas shows his deep distress with the legacy that, consequently, would be left for future generations: destroyed forests, polluted waters, contaminated atmosphere and a natural system deserted of various animal species. His proposal is that of owning responsibility by each individual in relation to "everything" that exists - living beings, nature, planet, and universe. The ideas defended by Jonas can, then, be considered as conductive to a systemic paradigm.

The appearance of new paradigms in Physics and in Biology would open paths for a new way of dealing with reality, in opposition to the reductionist-mechanical thought: the systemic paradigm. Even though it is not in opposition to scientific rationality, the systemic paradigm considers that such rationality doesn't offer enough parameters for human development and for the description of the material universe,

\footnotetext{
${ }^{11}$ HOSS, GM, Resenha/Review: Fritz Jahr and the foundations of global bioethics - the future of integrative bioethics, in Revista do Centro Universitário São Camilo, 2 (2012) 237-239, edit by Amir Muzur, Hans-Martin Sass

${ }^{12}$ JAHR, F., Bio-Ethic: eine umschau über die ethischen. Beziehungen des menschen zu tier und pflanze, in Kosmos Handweiser für Naturfreunde, 1 (1927) 3

${ }^{13}$ HOSS, GM, Resenha/Review: Fritz Jahr and the foundations of global bioethics - the future of integrative bioethics, cit.

${ }^{14}$ Ibid.

${ }^{15}$ JONAS, H., O princípio responsabilidade: ensaio de uma ética para a civilização tecnológica (Rio de Janeiro 2006)
} 
defending that reality should be conjoined with the subjectivity of the arts and spiritual traditions. Its representatives are scientists, researchers, philosophers and intellectuals of various fields. With the systemic paradigm, science admits that everything is interconnected, and so new world visions arise, like the ecocentric and bio-centric. From the perspective of eco-centrism, it is the ecosphere the center of humanity's value - no longer man. Ethic becomes eco-centric, planetary, and systemic. The interconnection between every thing and the interdependence of everything that lives are therefore acknowledged.

In this systemic line of thought comes Peter Whitehouse, from the University of Cleveland, who "assumes the idea of advancements in evolutionary biology, and especially, with the systemic and complex thought that comprises biological systems", according to Pessini and Barchifontaine. ${ }^{16}$ In 1998, according with Pessini, ${ }^{17}$ Van Rensselaer Potter retakes Whitehouse's thought by presenting his idea of a Deep Bioethics, which intends to understand the planet as a set of biological systems intertwined and interdependent, with the center no longer represented by man, but by life itself. Man then is seen as a link in a great net of life, a thought that already appeared in 1973 with philosopher Arne Næss. ${ }^{18}$ Næss' perspective gives continuity to a sequence to the tradition of the ecological-philosophical school of thought presented by Henry Thoreau, in "Walden", and Aldo Leopold in "A Land Ethic".

From the systemic view of the world, emerges bio-centrism, a more evolved form of eco-centrism. According to the new concept, which was proposed by medical doctor Robert Lanza, ${ }^{19}$ every life is interconnected, having no divisions between humanity and the environment, and life being of value before all other things. Life, through bio-centrist view, has a generic value, not being an exclusive right to man, but to all that lives. Lanza ${ }^{20}$ attributes to consciousness the fundamental role of creating life in the universe, contradicting the classic theory that the universe creates life. In the vision of theoretical physicist Fritjof Capra, ${ }^{21}$ the new paradigm can be denominated holistic, ecological or systemic. He doesn't just look at something as a sum, but also sees to the way such sum is embedded into bigger sums.

An entire sequence of events, therefore, would end up shaking the old paradigms and make a historical moment where rationalism was no longer being well accepted. In a special way, a set of thoughts regarding nature and shared responsibilities would bring relevance to Environmental Law, representing, in accordance to Milaré, ${ }^{22}$ factors that made space so that Animal Law would become necessary as an autonomous discipline.

\section{The slow and difficult path of Environmental Law and Animal Law}

The space opening for Animal Law and the struggle for its recognition as an autonomous discipline could not have happened before, in the time period that was still ruled by rationalism. The process would not have been met with smooth approval, since an inherent trait of rationalism can be exemplified as that of humans not being worried with nature or with non-human beings, and being convinced by the notion that man is a different and superior being on the planet. Empirical rationalism, particularly, was then the carrier of all the justifications for the control and unbridled exploitation of nature, an exploitation that, one cannot deny, was determinant for technological progress.

In the field of Law, generally, the influence of the Cartesian-Newtonian paradigm became patent within the laws that, for centuries, ruled the lives of human beings. Adopting for a long period legal positivism, defended by Kant, the science of Law would remain attached to this mechanical doctrine that, disassociating fact and value, it equally disassociated from morality the application of justice. Comprising a strictly objective view of Law, a view based on legal positivism, it was understood, then, that what was defined within the law was valid; fair would be only that which is described in the law. And being man the focus to which all laws converged to, the end result couldn't be different: if justice is only applicable to men, and if the law was justice, there wouldn't be laws that covered animals or the environment.

Looking back at History, one must admit that animals haven't been a primordial issue for science. It can be said that first man looked up to the sky, observing and analyzing the elements of the celestial scenery. Afterwards came human matters. Only recently, and as consequence of various ethical, social and

\footnotetext{
${ }^{16}$ PESSINI, L., BARCHIFONTAINE, CP, Problemas atuais de bioética (São Paulo/Centro Universitário São Camilo 2007) 37

17 PESSINI, L, As origens da bioética: do credo bioético de Potter ao imperativo bioético de Fritz Jahr, in Revista Bioética, 1 (2013) 9-19

${ }^{18}$ NAESS, A, The shalow and the deep, long-range ecology movement: a summary, in Inquiry, 16 (1973) 95-100

${ }^{19}$ LANZA, R., Biocentrismo, in Pensar Além, November 21, 2009, in http://pensaralem.wordpress.com/2013/11/21/biocentrismorobert-lanza-2009/ [last visited 10 February 2019]

${ }^{20}$ Ibid.

${ }^{21}$ CAPRA, F., Pertencendo ao universo: explorações nas fronteiras da ciência e da espiritualidade (São Paulo 1991)

${ }^{22}$ MILARÉ, É., Direito do ambiente, in Revista dos Tribunais (2011) 119
} 
political crises, has science turned its eyes towards the environment and animals. However, as discussed regarding scientific revolutions, it becomes inevitable that, at a certain point in History, a new paradigm related to the knowledge or view on a fact replaces the previous one as result of the social dynamic itself, and many times based on shocking discoveries. Hence, Environmental Law and Animal Rights wouldn't be an exception to the rule.

Man, being at the center of the theories of Law, stopped being the center of creation after Darwin's Theory of Evolution, a theory whose reach could not, nor should be ignored by Law. The scientific knowledge propelled the motions of social dynamics, with humanity being surprised with discoveries in the fields of electricity, electro-chemistry and magnetism, novelties that accumulated and demanded minds to open and that the awareness about the world expanded. The principle of uncertainty, which Werner Heisenberg [1901-1976] introduced in Physics, not only solidified the new scientific paradigms but also influenced the paradigms of other fields of science, including applied social sciences, among which was Law. And, in this new world scenario, Jonas, ${ }^{23}$ when presenting his theory of responsibility, admonishes the man of science to be humble, to recognize the fallacy of many of his theories, to see that indetermination contaminates what before was an irreducible "scientific truth", to accept that, with time, any process can change or extinguish without science being able to bring a perfect explanation or prediction. To generate or apply knowledge would now be a process pervaded with real humility, with the end of a supposed and immutable knowledge superiority by scientists or technicians so that, in this way, there could be a balance between technology and ethics. This balance was not being taken into account, according to Jonas, who saw humbleness as a necessary antidote to what he calls current technological arrogance.

The union of these many factors that composed the stage for an old paradigms crisis starts to bring results. In the fields of Science and of Law, step-by-step, the environment and its inhabitants start gaining a different role. In 2000, comes the first doctorate thesis that tackles the issue of animal rights defended in a Law Faculty in Brazil (Federal University of Minas Gerais). In her text, Dias ${ }^{24}$ draws attention to the planetary crisis, a factor that, due to its direct consequences on fauna and flora, demand from science a new stand, a significant change in perspective. The planetary crisis, as explained by the author, caused the emergence of a holistic paradigm, reoriented by a worldview. Holos, in Greek, means "all" and the holistic seeks to unite the whole in relation to its parts. In the new paradigm, science must understand reality as a net of relations. The field of action, finishes the author, embraces a web of intrinsically dynamic relationships that does not deal with exact truths.

The sequence of large ecological disasters and the planetary crises taking place in the last few years are forcing an acknowledgement of a taxing need to broadly discuss about the issue of environmental protection. And, in that reality where the planet is found under the threat of destruction, it becomes automatically indispensable the creation of laws and norms that safeguard the ecosystem. As a consequence, Environmental Law begins to gain more attention, whereas Animal Law - which is still treated as a transversal matter within Environmental Law -, is questioned, alerting to the primordial role that animals have to play in the planet.

Additionally, the ethical and moral crisis that's been occurring causes the introduction of new paradigms and new values in the relationship between humans and non-humans. The violence witnessed at every moment and everywhere in the planet creates in man the aspiration for peace, for respect towards moral values, for consciousness of the individual and social responsibility - an aspiration that cannot be restrained to the circle of men, before the proposition of so many thinkers and scientists regarding the interconnectedness of everything and between all. The barriers - such as the ones resulting from race, religion, culture or others - stop being considered as proper or harmonious conditions for the ideal of a peaceful world. On that same note, the distorted relationship between man and animals demands rectifications in order to adapt to the new paradigms.

Among the fruits that have been harvested due to the change in perspective, one can verify that the rights of animals have already begun to integrate social moral values, in some societies, being nowadays recognized by laws and codes, and debated in some courts, advancing towards the moment where they become part of the moral values of all nations. In some countries right now, animals are considered to be supranational rights holders, rights that are acknowledged in treaties and international conventions. Hence, today animals integrate, in some capacity and in some more or less effective way, the internal legislation of some civilized countries.

\section{The trajectory of animal rights theory}

\footnotetext{
${ }^{23}$ JONAS, H., O princípio responsabilidade: ensaio de uma ética para a civilização tecnológica, cit

${ }^{24}$ DIAS, EC, Tutela jurídica dos animais (Belo Horizonte 2000)
} 
The expression "animal rights" is used for the first time by English writer, humanitarian and social reformer Henry Salt [1851-1939], one of the pioneers in the debate about the existence of such rights. In 1975, Salt's life and his work deserve the reference and consideration of Peter Singer, ${ }^{25}$ introducer of the theory of animal liberation. For Singer, the book that Salt called "Animals' Rights: Considered in Relation to Social Progress", originally published in 1894, is one of the essential works in defense of animal rights.

In page 2 of the aforementioned text, Salt defends that "the notion of the life of an animal having no 'moral purpose' belongs to a class of ideas which cannot possibly be accepted by the advanced humanitarian thought of the present day - it is a purely arbitrary assumption, at variance with our best instincts, at variance with our best science, and absolutely fatal (if the subject be clearly thought out) to any full realization of animals' rights. If we are ever going to do justice to the lower races, we must get rid of the antiquated notion of a 'great gulf' fixed between them and mankind, and must recognize the common bond of humanity that unites all living beings in one universal brotherhood." 26

Salt ${ }^{27}$ brings attention to animal rights in a non-aggressive manner (a trait that made him a highly valued example in the transformation and positive propagation of ethical vegetarianism), and refutes speciesist justifications that have been repeated for years, defending the importance of an intellectual, literary and social crusade against animal oppression. For him, the reality of animals' lives could be compared to the reality of slaves' lives. Deceiving are the discourses made against animal rights and animal abolitionism, Salt concludes.

English theologian Humphrey Primatt [1735-1776], previous to Salt, does not use the term "animal rights", but defend these same rights when adopting the parameter of "ability to suffer" to speak about moral consideration. In "A Dissertation on the Duty of Mercy and the Sin of Cruelty to Brute Animals", a text from 1776, he defends the duty of compassion from men to animals. ${ }^{28}$ As Lourenço explains, ${ }^{29}$ this line of thought was embraced by Jeremy Bentham [1747-1832] in his book "An Introduction to the Principles of Morals and Legislation", from 1789, when the British philosopher affirms that the possession of sentience, and not rationality, should grant moral consideration to a being.

Bentham ${ }^{30}$ offers, since the first editions of his book, passages that attribute feelings and/or emotions to animals, and regrets that uncaring jurists still classify animals as things, as in this citation originally presented in 1781:

IV. What other agents exist, that, at the same time they are under the direct influence of man, are susceptible to happiness? They are of two kinds: 1. Other human beings, who are called people. 2. Other animals, which, having their interests neglected by the insensitivity of old jurists, continue to be reduced to the level of things. ${ }^{31}$

Affirmations of equal seriousness are presented by philosopher and physician Albert Schweitzer [1875-1965], who includes all living beings in the ideal sphere of compassion, which he sees as the basis of ethics:

It is believed that compassion, where ethics is firmly rooted, does not assume its real proportions until it embraces not just man, but all living creatures. To the old ethics, which did not possess such deepness and strength of conviction, was added the ethics of reverence towards life, whose validity has been gaining constant recognition. ${ }^{32}$

Schweitzer, who is considered as one of Van Rensselaer Potter inspirations in the creation of the contemporary concept of Bioethics, affirms, in 1952, when receiving the Nobel Peace Prize: "Ethics consists, then, in my compulsive experience in providing all 'beings-that-live-and-want-to-live' the same

\footnotetext{
${ }^{25}$ SINGER, P., Libertação animal (Porto Alegre 2004)

${ }^{26}$ SALT, H., Animals' Rights: Considered in Relation to Social Progress (Pennsylvania 1980) 2

${ }^{27}$ Ibid.

28 PRIMATT, H., A dissertation on the duty of mercy and sin of cruelty to brute animals, 1776, in Animal Rights History, in http://www.animalrightshistory.org/animal-rights-c1660-1785/enlightenment-p/pri-humphrey-primatt/1776-mercy-cruelty.htm [last visited 23 April 2019]

${ }^{29}$ LOURENÇO, DB, Direito dos Animais: fundamentação e novas perspectivas (Porto Alegre 2008)

${ }^{30}$ BENTHAM, J., An introduction to the principles of morals and legislation (Kitchener 2000)

${ }^{31}$ Ibid. 225 (own translation)

32 SCHWEITZER, A., The problem of peace, in HABERMAN, FW (Edit.), Nobel lectures: Peace 1951-1970, Elsevier, Amsterdam (1972) (speech of November 1954) 309 (own translation), in http://nobelprize.org [last visited 2 February 2019]
} 
reverence that I give myself." ${ }^{33}$

In 1975, Peter Singer publishes "Animal Liberation", ${ }^{34}$ a book that denounces the suffering and unfair treatment given unto animals. His text is considered to be one of the philosophical pillars of the animal liberation movement, as well as for the formation of the theory of animal rights. For Singer, animals should be included in human's moral consideration and, due to their condition as sentient beings, should have their interests taken into consideration as much as human interests, as Dias points out. ${ }^{35}$ Besides this introduction of animals within the moral community, Singer insists that the key point for animal liberation is the consideration of interests, with the equal consideration of interests based on the ability that animals have to suffer. ${ }^{36}$ In the book "Practical Ethics", Singer broadens these topics. ${ }^{37} \mathrm{He}$ argues that, because they are endowed with sensitivity and consciousness, animals should be treated with the same respect that humans are treated with. He considers once more that the principle of equal consideration of interests should be applied without distinction between human and non-human animals and that the ability to suffer and feel pain should be a pre-requisite to measure interests.

North-American philosopher Tom Regan is known to be the great defender of the animal abolitionism theory. His claim is that the ethical principle should be extended to animals, as well as the inherent value to each individual. ${ }^{38}$ Characterizing animals as subjects-of-a-life, he preaches the end of every kind of animal exploitation. ${ }^{39}$ Regarding abolitionism, jurist and philosopher Heron Gordilho completes:

Legal scholars like Steven Wise, Gary Francione and Jean-Pierre Marguenau are, however, more worried with attributing a legal personhood to animals, in order to guarantee them the capacity to acquire rights and defend them in court through their representatives. ${ }^{40}$

The year of 2000 proved to be outstanding in the issue of animal presence in the legal world. The concept of an animal as a subject of rights expanded that year throughout the world and, as corollary, the animal rights theory begins to take shape and to gain strength. As previously seen, in 2000 is introduced in Brazil's academic world the idea of the animal as subject of rights, through the thesis presented by Dias. ${ }^{41}$ This work is based in a decision made by the Supreme Court of the United States, when the animal was considered as a subject of rights in the conception of American Judge Christopher Douglas Stone. The vote of Judge Stone was given in the case Sierra Club versus Morton (Toward Legal Rights Objects, 445. S. Cal. I. Ver. 450 - 1972), when there was an annulment requirement of a decision by the U.S. Forest Service, which gave permission to Mineral King Valley to build a ski resort in an almost wild area. Discussing the argument presented by Stone, Dias highlights:

Judge Douglas Stone, in his vote, argued that inanimate objects are, sometimes, parties to the dispute. And, just like a ship has legal personhood and a simple corporation is a person for legal purposes, nature can also be a subject of rights. ${ }^{42}$

The issue is also considered by professor José Alfredo Baracho Júnior, in "Civil Responsibility for Environmental Damages" (own translation).$^{43}$ Baracho Júnior draws attention to the position adopted by the North-American jurist in his article "Should trees have standing?", ${ }^{44}$ where he presents the idea that the legal norms of environmental protection constitute a form of attributing subjective rights to animals and plants. As pointed out by Dias, ${ }^{45}$ following that same thought, "The associations and public agents that litigate in Court in defense of the environment are acting as its representatives." She also defends Stone in her discourse that, although trees and plants are not human beings, they are individuals, as they are recognizable in a singular way. As developed in Dias, ${ }^{46}$ these acknowledgements of rights of animals and plants constitute an evolution in the process of declaration of rights that was extended from whites to blacks,

\footnotetext{
${ }^{33}$ Ibid. 309

${ }^{34}$ SINGER, P., Libertação animal, cit.

${ }^{35}$ DIAS, EC, Bioética e direitos dos animais, in Fórum de Direito Urbano e Ambiental - FDUA, 43 (2009) 16-21

${ }^{36}$ SINGER, P., Libertação animal, cit.

${ }^{37}$ SINGER, P., Ética prática (São Paulo 2002)

${ }^{38}$ REGAN, T., The case for animal rights (Berkeley and Los Angeles 2004)

${ }^{39}$ REGAN, T., Jaulas Vazias (Porto Alegre 2006)

${ }^{40}$ GORDILHO, HJS, Abolicionismo animal (Salvador 2009) 75

${ }^{41}$ DIAS, EC, Tutela jurídica dos animais, cit.

${ }^{42}$ Ibid. $84-86$

${ }^{43}$ BARACHO JUNIOR, JAO, Responsabilidade civil por dano ao meio ambiente (Belo Horizonte 2000)

${ }^{44}$ STONE, C., Should trees have standing? Toward legal rights for natural objects, in Law Review, 45 (1972) 450-481

${ }^{45}$ DIAS, EC, Tutela jurídica dos animais, cit. 86

${ }^{46}$ Ibid.
} 
natives, women, and other minorities.

As seen above, Judge Stone uses, at a certain point in his vote, the example of a ship having legal personhood and of a ordinary corporation being considered a person for legal purposes. A point that needs attention here is the recognition of the so-called legal fiction during debates about what can and cannot be considered a person in the field of Law. Based on the explanations of Salles, ${ }^{47}$ one can initially verify that there are, within the legal universe, a "physical person", which is the human being, and a "legal person", which is a legal fiction (in other words, an invention from Law), who has rights and obligations. The distinction between these persons, as well as the given traits to each one of them, will reveal important points for the present discussion.

From Salles' exposition, ${ }^{48}$ we know that, fictionally, a legal person becomes an "entity", no longer a "thing", having, in some cases, more rights than a physical person. The physical person, by their turn, is seen as a "person with personalized rights", being able to be also a "physical person with depersonalized rights". Anencephalic individuals, who are condemned to a vegetative life, can exemplify this last case. However, the denomination "physical person with depersonalized rights" covers a much wider ground, being able to be applied, as exemplified and taught by Lisboa, ${ }^{49}$ to even a failed mass of a business.

It is fitting then to bring here the teachings of Lourenço, ${ }^{50}$ when stating that a theory of depersonalized entities founded on the concepts of "person" and "subject of rights" allows one to dismiss the qualification of the entity as "person" so that it can claim subjective rights. Supported in this affirmation, Coelho ${ }^{51}$ proposed that animals should be considered true depersonalized, non-human subjects of rights, no longer being "things". In accordance with Lourenço's observations, ${ }^{52}$ the theory's objective is to turn animals into "subjects of rights", not mattering if they are "depersonalized", so that they can enjoy a legal patrimony that guarantees them the bare minimum. Salles denies shelter to Coelho's proposition, arguing: "Why personalize a thing as an asset, and depersonalize a mammalian animal that possess, in practical life, real biological and psychological personalities? It would be like giving life to an object (legal personhood) and taking away a life from a living being, transforming into a thing (res)." 53

The issue of classifying or not classifying an animal as a "person" generated, from Lourenço's side ${ }^{54}$ a thesis that, in the opinion of the author himself, is very bold. Considering that his arguments deserve mentioning in the present discussion, a summary of them made by Salles was used here:

The Federal Constitution (1988) uses the word "person", and not "man", when it wants to refer to a human being, qualifying with the word "human", as it happens in art. $1^{\text {st }}$, subsections III and VII, and in art. $225, \S 7^{\text {th }}$. At first sight, this fact may seem of no importance, one even thinking that the word choice happened only to de-characterize the "patriarchal" concept that is given to the word "man", replacing it for "human person". However, a more careful interpretation of this substitution reveals that, when qualifying the abstract noun "person", the constitutional norm creates a concept that is ontologically distinct, which is that of "human person". Stemming from the assumption that constitutes a basic hermeneutic principle that the legal norm cannot contain futile words or expressions, one can take from here that the Constitution indirectly recognizes, then, the existence of non-human persons, in contraposition to human persons, because otherwise, it would be enough to adopt the term "person" when it wanted to refer to human beings and nothing else. ${ }^{55}$

Even more appropriate is to consider the historical moment in which the word was used. One needs to only remember that, for centuries, women and slaves weren't called "persons", and that the mentally or physically challenged also weren't considered "persons". It can be easily seen that the use of the term depended on choices connected to a variety of factors, for example, politics, economics, and culture. Regarding the issue, Kelsen ${ }^{56}$ affirms that the concept of "person" belongs to the legal reality and not to

\footnotetext{
${ }^{47}$ SALLES, AA, Uma bioética e hipotética petição inicial: subsídios para a caracterização do animal como pessoa física não humana no Direito brasileiro, in BIZAWU, SK (Coord.), Direito dos Animais: desafios e perspectivas da proteção internacional, Arraes, Belo Horizonte (2015) 91-122

${ }^{48}$ Ibid.

${ }^{49}$ LISBOA, RS, Teoria geral do Direito Civil (São Paulo 2010)

${ }^{50}$ LOURENÇO, DB, Direito dos Animais: fundamentação e novas perspectivas, cit.

${ }^{51}$ COELHO, FU, Curso de Direito Civil (São Paulo 2003)

${ }^{52}$ LOURENÇO, DB, Direito dos Animais: fundamentação e novas perspectivas, cit.

${ }^{53}$ SALLES, AA, Uma bioética e hipotética petição inicial: subsídios para a caracterização do animal como pessoa física não humana no Direito brasileiro, cit., 112

${ }^{54}$ LOURENÇO, DB, Direito dos Animais: fundamentação e novas perspectivas, cit.

${ }^{55}$ SALLES, AA, Uma bioética e hipotética petição inicial: subsídios para a caracterização do animal como pessoa física não humana no Direito brasileiro, cit., 114-115

${ }^{56}$ KELSEN, H., Teoria geral do Direito e do Estado (São Paulo 1995)

38 Derecho Animal. Forum of Animal Law Studies, vol. 10/3
} 
factual or biological reality. This way, he explains, the concept can present a diverse content, according to the political and cultural options from different historical and cultural moments, which lead to understandings that are also unique to each one of these moments.

Arguments such as the one mentioned above lead us to agree with authors such as Lourenço, ${ }^{57}$ when he affirms that the seemingly legal certainties need and should be questioned from the historical moment when they no longer offer solutions to social demands. The dichotomy subject-thing in relation to animals should then be questioned, within the legal scenario, a topic that needs urgent revisiting. When considering important to reclassify animals, it is not at all with the objective of de-classifying the human species. The endeavor is, using the words of Costa Neto:

"For the intrinsic valuing of animals and of nature, understanding that, as actors of the same biotic scenario, it is up to human beings the adoption of an ecological interpretation and an ethical stand that surpasses the anthropocentric and selfish position that nature and non-human animals are there only for the satisfaction of our needs." 58

Regarding the issue, Salles said:

The use of the term "legal person" in reference to organizations, corporations and similar, by Civil Law, implies, in our view, an abstract reasoning, and gives ground for questioning: if Law can make such an abstract reasoning to understand the notion of legal person, why not extend this abstraction to animals as "zoological persons"? "De-rational persons"? "Animal persons"? Or, simply, as "nonhuman physical persons"? ${ }^{59}$

Drawing attention to the motivation that allows the Law to be flexible in its terminology, the author adds:

When we look in an honest manner the issue of denominations or classifications in Law, we verify that if suffers a strong influence from the interests of the dominant classes. We have examples in History that show that, when certain classifications were advantageous to the driving classes of the country and the Law molded itself to satisfy them. One of these moments was during Imperial Brazil regarding the black slaves. In Civil Law, the slave was a res, in other words, an object. As such, it could be exchanged, sold, borrowed, bought, and even discarded when it was no longer useful for its owner. However, according to Penal Law, if that same slave attacked its owner, or tried to escape, it became a person, a person that was aware of their actions and that could (and was) cruelly penalized for their (seeming) faults or offenses. ${ }^{60}$

It is fitting the doubt expressed by Machado: "How is it possible that Law worries so little about animals when, at the end, we are related to them and we use them for various reasons?". ${ }^{61}$ The one to answer is Medeiros:

The answer to such interrogation is maybe within the legal science itself, which, from ancient times, it is more preoccupied with property than with life. Possibly, the problem is within: human animals that do not know how to even deal with their humanity nor with their animalism. ${ }^{62}$

Working on the issue of recognizing the fundamental rights of living beings, legal scholar of Animal Law in Harvard, Steven M. Wise, ${ }^{63}$ defends that the recognition must be connected to the autonomy and self-determination of the being, and not to their capacity to suffer. The judges, how he sees it, do not take into consideration an animal's ability to suffer, but their autonomy when pronouncing their sentences.

Based on the autonomy criteria, Wise ${ }^{64}$ defined that a being has autonomy when 1) it has interests; 2)

\footnotetext{
${ }^{57}$ LOURENÇO, DB, Direito dos Animais: fundamentação e novas perspectivas, cit.

${ }^{58}$ COSTA NETO, NDC, Proteção jurídica do meio ambiente - florestas (Belo Horizonte 2003) 32

${ }^{59}$ SALLES, AA, Uma bioética e hipotética petição inicial: subsídios para a caracterização do animal como pessoa física não humana

no Direito brasileiro, cit., 116

${ }^{60}$ Ibid. 116

${ }^{61}$ MACHADO, SM et al., Los animales y el Derecho (Madrid 1999) 18

${ }^{62}$ MEDEIROS, FLF, Direito dos animais (Porto Alegre 2013) 206

${ }^{63}$ WISE, SM, Animal thing to animal person - Thoughts on time, place, and theories, in Animal Law, 5 (1999) 61-68

${ }^{64}$ WISE, SM, Lecture in I Congresso Mundial de Bioética e Direito Animal, Universidade Federal da Bahia (UFBA), Salvador,
} 
can intentionally try to satisfy them; and 3) has a sense of self-sufficiency that allows it to understand, even at a minimal level, that it is it who wants something and that it is it who is trying to reach that something. Hence, from Wise's perspective, ${ }^{65}$ the holder of such autonomy should have their fundamental rights guaranteed, or, as Wise calls, the "rights to dignity". In the quality of living beings, animals should deserve equal legal consideration, as most of the time they possess all the traits demanded from humans, and sometimes, even at a higher level of sophistication.

At this point, some aspects of the abolitionist theory need addressing, as the ones exposed by philosopher and professor of Law at Rutgers University, Gary Francione. He brings to the debate the fact that "legal welfare" suggests that a confrontation between human interests with that of animals should take place in order to conclude that the suffering of an animal is justifiable or not. Using such perspective, according to Francione, ${ }^{66}$ the inevitable result will be that human rights will always be considered more relevant, and the interests of animals always being relegated to the background. He also verifies, when examining the welfare legislation, that it is a legislation that defends improvements, but that within its perimeters, the animal continue to be subject to property laws and submitted to cruelty if this attends to economic interests. This way, it is perpetuated the notion that animals are resources, things, objects.

Still according to welfare, we can use non-human animals if we do not submit them to unnecessary suffering, a condition that Francione ${ }^{67}$ vehemently disputes, complementing that talking about "necessary suffering" is an indefensible thesis. Here, what can be verified is, if the animal is considered property, the regulation for animal use is unable to protect it, meaning that the animals would only have the value that we granted them. The condition of property, inevitably, must be viewed as a limiting factor in the protection of animals. The animal, sustains Francione, has intrinsic value, whereas property has extrinsic value - if the animal is liable for property law, there will always be a way to use it for economic, legal, social and political purposes. Considering the animal as property, warns the author, it won't be possible to grant equal consideration to the animals in relation to humans; therefor, he reiterates, it will be considered from the perspective of human interests.

\section{Fundamental rights of animals and its legislation}

Fundamental rights, as it is reviewed here, keep the fundamental values and principles of the juridical order of a country, and are recognized and affirmed rights by the constitutions of the nations. The rights of animals incorporated in the Constitution of the Federative Republic of Brazil from $1988^{68}$ are originated from the rights of animals constantly found in international treaties and recognized by Brazil. In the Constitution, they are stone clauses, devices that are characterized for imposing the rigidity of certain precepts. They are dispositions that are unsusceptible to being abolished through amendments, constituting an irreversible nucleus of the Constitution. Such precepts have supremacy over all other interests.

The dictates of the Brazilian legislation regarding animals deserve a careful consideration. Article 225 of our Constitution of 1988, in subsection VII of $\S 1^{\text {st }}$, elucidates:

Art. 225. All have the right to an ecologically balanced environment, a good of common use of the people and essential to a healthy quality of life, demanding from the Public Power and society the duty to defend it and preserve it for present and future generations.

$\S 1^{\text {st }}$ To ensure the effectiveness of this right, it is up to the Public Power to:

VII - protect the fauna and flora, prohibited, in the form of law, practices that put at risk their ecological function, provoke the extinction of species or submit animals to cruelty.

It can be certified, then, that the rights of animals are recognized by the Constitution and that the Magna Carta presents a commandment of non-cruelty through subsection VII, reproduced above. On the other hand, with the dispositions of art. 225, there was room for the establishment of a new juridical status of the environment, which was characterized as a 'good of common use of the people'. The fauna and flora of the country, considered parts of the environment, are, consequently, goods of common use of the people, a kind of diffused good to be preserved for future generations. In conclusion, the Brazilian fauna is property of the nation and of society.

\footnotetext{
October 8 (2008)

${ }^{65}$ Ibid.

${ }^{66}$ FRANCIONE, GL, Animals as persons (New York 2008)

${ }^{67}$ Ibid.

${ }^{68}$ CONSTITUIÇÃO da República Federativa do Brasil de 1988, in

http://www.planalto.gov.br/ccivil_03/constituicao/constituicao.htm [last visited: 14 March 2019]

40 Derecho Animal. Forum of Animal Law Studies, vol. 10/3
} 
Property, within the Brazilian Constitution, is conditioned to its social function and to the protection of the environment. The fauna of the country is considered, in accordance with Law $n^{\circ} 6.938$, of August $31^{\text {st }}$, $1981,{ }^{69}$ in its art. $3^{\text {rd }}, \mathrm{V}$, an environmental resource. So, at the moment, the legal nature of animals in our legislation is an obstacle for a differing reasoning to prevail from the one rooted in popular consciousness, the argument that an animal is a good. It can be seen as a collective good in the case of wild animals, which are classified by legislation as a good of common use of the people, an impartible and unavailable diffused good. Or, it is considered res nullius, a private property, in the case of domestic animals.

In any case, the animal continues to be considered property in Brazil, despite having a few noticeable differentiations of the applicable laws to them. If the animal is classified as a good of common use of the people, the rules imposed by law regarding them are stricter - they are unavailable, unalienable, impermissible, and have imprescriptible rights. If the animal is classified as a mobile good, however, it is an object passible of having an owner or tutor that can, in relation to this animal, use, enjoy, dispose of and claim. If it is res nullius, a human can appropriate it. Nevertheless, the property of an animal by a human, it is important to notice, is subject to limitations predicted by law. These limits seek to ensure that the animal is not subjected to cruelty and that it is not denied the right to welfare - which are looser limits than those imposed in the relationship with wild animals.

Animals are not people. Animals are not things. Animals are animals. Still, that is not the perspective coming from the Brazilian Civil Code of 2002..$^{70}$ This device brings, in its general part, the title "Of Persons", in Book I, and in Book II, "Of Goods". In the latter, under Title I, is found Section II, "On Mobile Goods", where it is included article 82, which says: "Are mobile the goods susceptible to independent movement, or removal through external force, without alteration in substance or economical-social destination." It is based on this article 82 that, in our country, animals are classified as goods susceptible of independent movement or removal through external force.

As if trapped in a snare represented by a code that only enables two classifications - persons and goods - Brazilian scholars are many times brought to classify the animal as object of rights (a good), and not as a subject of rights. In regardless, animals are granted supranational rights (as asserted by the Universal Declaration of Animal Rights, 1978 ${ }^{71}$ ), of fundamental rights (as observed in the Brazilian Constitution of 1988 , in art. 227, $\S 1^{\text {st }}$, VII), and of legal rights (according to Law $n^{\circ} 5.197$, of $1967,{ }^{72}$ that regards Fauna Protection, and Law $\mathrm{n}^{\circ} 9.605$, of $1998,{ }^{73}$ which regards Environmental Crimes). And, additionally, as shown by Silva, ${ }^{74}$ animals can go to court by substitution or representation. Hence, there shouldn't be any question whether animals are or not subjects of rights. And, as subjects of rights, they can be withholders of rights provided in laws, which allows that these rights may be defended in court.

To classify animals as goods represents a vision that is incompatible with the new paradigm that is taking place in the world, especially in more advanced countries. In Switzerland, for example, their legislation already classify animals as animals. In France, in January of 2015, in a decision considered historical, the Civil Code is altered. On par with the analysis by Fondation 30 Millions d'Amis, ${ }^{75}$ the animal is now recognized as "a living being endowed with sensitivity" (by article 515-14), and no longer a mobile good. Thus, the animal is no longer defined by its patrimonial and commercial value, but by its intrinsic value. With that, the Civil Code harmonizes with the Rural Code and the Penal Code of the same country. These are the examples that should guide a theory of animal rights in our country. It is imperious the inclusion of a third category in our national Civil Code, in order to enable that the animal is recognized as a sentient being, different from a person and a good. Above all, an animal is a living being and it is as such that it needs to be perceived as: a living being capable of acquiring rights. Only in this context will the minimum of moral rights and right to dignity be granted.

Having as truthful that the animal is a being with its own interests, such as existing, safety, to not

\footnotetext{
${ }^{69}$ Law 6,938, August 31, 1981, in http://www.planalto.gov.br/ccivil_03/leis/16938.htm [last visited 10 March 2019]

${ }^{70}$ Law 10,406, January 10, 2002 (Código Civil), in http://www.planalto.gov.br/ccivil_03/leis/2002/110406.htm [last visited 13 February 2019]

${ }^{71}$ UNESCO, Declaração Universal dos Direitos dos Animais, Bruxelas January 27, 1978, in Portal do Conselho Federal de Medicina Veterinária, in http://portal.cfmv.gov.br/uploads/direitos.pdf [last visited 14 February 2019]

${ }^{72}$ Law 5,197, January 3, 1967, in http://www.planalto.gov.br/ccivil_03/leis/15197.htm [last visited 10 March 2019]

${ }^{73}$ Law 9,605, February 12, 1998, inhttp://www.planalto.gov.br/ccivil_03/leis/19605.htm [last visited 13 March 2019]

${ }^{74}$ SILVA, TTA, Animais em juízo (Salvador 2013) 162 and 167

75 FONDATION 30 MILLIONS D'AMIS. Statut juridique : les animaux reconnus définitivement comme des êtres sensibles dans le Code civil, 28 janv. 2015, in https:/www.30millionsdamis.fr/actualites/article/8451-statut-juridique-les-animaux-reconnusdefinitivement-comme-des-etres-sensibles-dans-le-code/. [Last visited 20 March 2019]. MANIFESTE, Pour une evolución du régime juridique de l'animal dans le code civil - Reconnaissant sa nature d'être sensible, Mars 2018, in http://www.30millionsdamis.fr/fileadmin/user_upload/actu/10-2013/Manifeste.pdf [ last visited 12 February 2019]
} 
suffer, and to live according to the needs of its species, is how we propose the "theory of rights and personality": the animal is a holder of rights, which can only be classified according to their own personality, which is neither that of a person nor of an object or good, but simply of an animal. Only when the idea that the animal is an object comes undone, will its dignity be restored.

\section{Animal Law as an autonomous discipline}

The Constitution of 1988, as seen above, acknowledges rights for animals in its article 225, and, going further, disposes of a commandment of no-cruelty in its subsection VII of $\S 1^{\text {st }}$. This backup coming from the Magna Carta leads us to consider that the recognition of animals' rights in Brazil has already overcome the moral sear and that it has become imperious the need to adopt a legal theory that recognizes the intrinsic value of the animal as a living, sentient being, backed by a change in its legal status.

Since all animals are under fauna, Animal Law has been studied in a transversal way within Environmental Law. There is a need, however, of reviewing this position for Law that presents all the necessary elements for its allocation as an independent subject. Data that bases this proposition can have its research started in the Brazilian Constitution of 1988 itself, in art. 225. According to this article, in its $\S 1^{\text {st }}$, the Public Power has the obligation to guarantee the right to life and to the ecosystem (subsection I); the right to preservation of biodiversity (subsection II); the right to species preservation and of animals not being submitted to cruelty (subsection III). An analysis of these devices shows, without error, the implicit idea that animals are holders of certain rights, as further explained below:

- RIGHT TO DIGNITY: It is a right that naturally exists due to the fact that the Public Power and society are in charge of guaranteeing life, whether in respect to physical integrity - here included the care that animals are not submitted to cruelty -, whether through the preservation of ecosystems and ecological balance.

- RIGHT TO EQUALITY: This right is the obvious result of the responsibility of the Public Power as well as society, in preserving life in its ecosystem regardless of the differences among its components, differences that have to be respected. As consequence of the obligations exposed in the article, there must be laws that prohibit practices that threaten the ecological balance, that put animals at risk of extinction, or that submit animals to cruelty.

In order for a treatment founded on equality to become applicable, a lot needs to be observed and studied in relation to a factor that has revealed to be a big hurdle to this egalitarian treatment: speciesism. The term, coined by Richard D. Ryder, a British psychologist, is used since the 1970s and refers to the regular discrimination that is practiced by humans against other species. In Ryder's understanding, ${ }^{76}$ such discrimination is based on physical differences morally irrelevant. One of the factors that would have motivated Ryder to create the term, tells Gordilho, ${ }^{77}$ would be his dedication against animal experimentation, as expressed in a handout from 1970, surfacing the word speciesism for the first time. In opposition to the discrimination of a being due to its species, there is anti-speciesism, which is the acknowledgment of equality of rights in accordance to the respective differences.

Although our Constitution does not use the term speciesism, it can be verified that that is the issue to be solved through laws, as it is based on the discrimination of animals as inferior beings that man believes that he can claim animals, mistreat them, torture them, and kill them. This treatment generated by such discrimination does not consider, or believes to be irrelevant, the fact that animals possess sensitivity, whether emotionally or physically. And regarding physical suffering, it was noted that Ryder ${ }^{78}$ developed the theory of painism; to express the ability to feel pain, he used the term painience (feeling pain), that he says is not applicable only to humans, but also animals. Condensing Ryder's vision ${ }^{79}$ the sensation of pain is the only convincing basis for the attribution of rights or even interests to another.

\footnotetext{
${ }^{76}$ RYDER, R., All beings that feel pain deserve human rights: equality of the species is the logical conclusion of post-Darwin morality, in The Guardian, Saturday 6 August (2000), in: http://www.theguardian.com/uk/2005/aug/06/animalwelfare [last visited 23 February 2019]

${ }_{77}$ GORDILHO, HJS, Abolicionismo animal, cit.

${ }^{78}$ RYDER, R., All beings that feel pain deserve human rights: equality of the species is the logical conclusion of post-Darwin morality, cit.

${ }^{79}$ Ibid.

42 Derecho Animal. Forum of Animal Law Studies, vol. 10/3
} 
- RIGHT TO FREEDOM: It is a right that finds its meaning in the Constitution's care regarding a well-balanced ecosystem. Animals can only survive to maintain the ecosystem whole and healthy if they live in their habitat, tending to their biological needs and protecting their natural sensibility.

- RIGHT TO LEGITIMACY: An obvious result from the constitutional article, the application of the norms is only possible if there is a regulation and the support of laws that guarantee the life and protection of animals.

- THE PRINCIPLE OF GENERAL DUTY AND SOLIDARITY BY ALL: Here can also be observed a natural result of the constitutional article since, without the compliance of general duty and solidarity, both from the Public Power and from society, the Constitution's devices cannot be fulfilled. The idea that protection rights for animals, that is implicit in art. 225 of the Constitution, can be made explicit through simple reasoning. It is defined, on one hand, that it is a responsibility of the Public Power and society to guarantee the rights to a balanced environment and to a good quality of life. On the other hand, it is known that democracy is a part of a State of rights and obligations. The conclusion we reached is that the rights of animals are equally general obligation and solidarity of all of us.

Thus become visible the incongruity in a legislation that recognizes some rights for animals and, at the same time, classifies them as goods, as things, as property. Consequently, it becomes clear the need for a change in the paradigms of Law. When Khun ${ }^{80}$ speaks about scientific revolutions, he mentions that they "begin with a growing feeling - and also restrained to a small subdivision of the scientific community - that the existing paradigm stopped working properly." When it comes to the rights owed to animals, the changes and crises that generate the emergence of a new paradigm have been present for a long time in Brazil and gradually intensifying the manifestations that the ruling paradigm of a Law that still classifies animals as "things" stopped working properly.

Studies that defend the need for a theory on animal rights are multiplying and, naturally, the need to include Animal Law as an autonomous subject in Brazilian universities. It is then necessary to notice what has been demanded in that sense and review, analyze and broaden what consists in Law regarding animals' rights, as means of advocating for a growing debate in universities' classrooms about the topic as an autonomous discipline.

Animal Law as an academic discipline has made its presence known in Brazilian institutions of Law. In a brief review based on the research of Silva, ${ }^{81}$ we have:

- In 2001, was thought in Pontifical Catholic University of Minas Gerais (PUC-MG), in the Nucleus of Legal Practice, the subject (trans-disciplinary) "Legal Guardianship of Animals". Teachers were: Edna Cardozo Dias (lawyer); Flávio Augusto Salim Nogueira (veterinarian) and Regina Bueno (veterinarian).

- In Pontifical Catholic University of Paraná (PUC-PR), in 2003, Prof. Danielle Tetü Rodrigues taught the discipline "Relation between Man and Nature" in the specialization module lato sensu in Environmental Law.

- A course of University Extension (post-graduation stricto sensu) denominated "Deep Studies of Bioethics and Animal Rights" took place at the Federal University of Bahia (UFBA), its coordinator being Prof. Heron Santana Gordilho. The study group was linked to the CNPQ (National Council for Scientific and Technological Development) at the Interdisciplinary Group of Teaching, Research and Extension on Animal Rights, Environment and Post-humanism (NIPEDA).

- Since 2008, the subject "Animal Rights and Deep Ecology" is being taught at the Federal University of the State of Rio de Janeiro (UNIRIO). At the Federal University of Rio de Janeiro (UFRJ), there is the Research Group of "Animal Rights and Deep Ecology Center". Their activities are taught and coordinated by Profs. Fábio Corrêa de Oliveira and Daniel Braga Lourenço.

- In the Postgraduate course in Environmental Law at the Legal Federal Study Center (CEAJUFE), in 2009, was taught the subject "Animal Rights", a specialization module lato sensu in Environmental Law, by Prof. Edna Cardozo Dias, and coordinated by Prof. Leandro Eustáquio Matos Monteiro.

\footnotetext{
${ }^{80}$ KUHN, TS, A estrutura das revoluções científicas, cit. 178

${ }^{81}$ SILVA, TTA, Direito animal \& ensino jurídico (Salvador 2014) 208-215
} 
With the examples shown above, there is enough reason and deep discussion material to justify specific studies about animal rights through an autonomous discipline.

\section{An invitation to reflection}

The acknowledgement of animals' rights is a process that has been dragging for decades. In the field of legal sciences, with the influence of Kant, for a long time only the human animal was considered as a being in itself. But, we have progressed. A little bit, and little by little. At the moment, it is accepted the theory of the indirect obligations that humans have towards animals. That means that the animal is still not the object of a direct moral consideration. Since man has the obligation to preserve the wellbeing of animals, if not contrary to human interests, we see that legal duty to comply with the animal protection laws only guarantee animals some rights indirectly. It is necessary, therefore, that the theories that stem from the concept of ethical defense, compassion, sentience, and the capacity to feel pain - such as Environmental Bioethics, for example - in relation to animals, find within Law a vast field and be applied immediately.

We saw the matter of the animal being or not a person when it is considered within the legal field. But we also saw that categorizations do not constitute a blockage in the making of laws, since legislators know how to use judicial fiction during the composition of the texts that will guarantee justice and rights for different groups of individuals.

Animals are not recognized, legally, as persons, but they are also not things or goods. They are living beings that inhabit the planet side-by-side humans. And, even though there already is a theory of rights in which their own legal rights are established, adjusted to the acknowledgement of their individuality and of their intrinsic value as living beings, such theory must be solidified. Only a theory thus characterized can constitute an unshakeable foundation so that, naturally following Animal Law, animal justice may be applied (within the gears of an administrative, procedural and legally adequate system).

Of everything that was expressed, it would be best if some considerations were not forgotten right after the reading of this article, but become topics for reflection and behavioral change by the reader.

All the beings that inhabit our planet in this moment are positioned within the same course of evolution, but it wouldn't be logical if they were ruled by identical rules or protected the same way. Regarding animals, change has been slow, but it is becoming more evident and agreed the need for Animal Law to have autonomy so that, strengthened and broadened, it enables the application of justice regarding the animals in the planet. And there won't be justice if it doesn't extend to all beings.

Man is not a superior animal, nor there is life that is inferior. All lives are important and play a specific role in the universal web of living beings. Plants, animals or humans, all are intertwined in the chain of life. And what affects one, can end up indirectly affecting another.

But man will need the humility proposed by Hans Jonas to recognize himself as a component in the net of life, and not as the main component that dictates the rules. What vary are the roles. Hence, each being needs to be respected for their role, their function, and their place inside the phenomenon of existence. If viewed this way, as beings that have a role, a purpose in their creation, a sui generis destiny to be fulfilled, animals can gain the space that was and still is being constantly taken from them, and need to be treated by what they really are - animals.

Animals that, living with humans, in nature, or between locations, in small or big cities, should have their rights as animals preserved. This is why there is urgency in caring for a theory of animal rights, and in bringing awareness to higher education about rights that need to be attributed and respected regarding them. Animals are part of the environment, it is true, but humans also are and deserved their own laws in accordance to their nature as humans. May they also be in accordance, within the juridical world, the rights of animals.

\section{REFERENCES}

- BARACHO JUNIOR, JAO, Responsabilidade civil por dano ao meio ambiente (Belo Horizonte 2000)

- BENTHAM, J., An introduction to the principles of morals and legislation (Kitchener 2000)

- CONSTITUIÇÃO da República Federativa do Brasil de 1988, in http://www.planalto.gov.br/ccivil_03/constituicao/constituicao.htm [last visited: 14 March 2019]

- Law 10,406, January 10, 2002 (Código Civil), in http://www.planalto.gov.br/ccivil_03/leis/2002/110406.htm [last visited 13 February 2019]

- Law 5,197, January 3, 1967, in http://www.planalto.gov.br/ccivil_03/leis/15197.htm [last visited 10 March 2019] 
- Law 6,938, August 31, 1981, in http://www.planalto.gov.br/ccivil_03/leis/16938.htm [last visited 10 March 2019]

- Law 9,605, February 12, 1998, inhttp://www.planalto.gov.br/ccivil_03/leis/19605.htm [last visited 13 March 2019]

- CAPRA, F., O tao da Física (São Paulo 1983)

- CAPRA, F., Pertencendo ao universo: explorações nas fronteiras da ciência e da espiritualidade (São Paulo 1991)

- COELHO, FU, Curso de Direito Civil (São Paulo 2003)

- COSTA NETO, NDC, Proteção jurídica do meio ambiente - florestas (Belo Horizonte 2003)

- CREMA, R., Introdução à visão holística: breve relato de viagem do velho ao novo paradigma (São Paulo 1988)

- DARWIN, C., The descent of man, and selection in relation to sex (London 2004)

- DIAS, EC, Bioética e direitos dos animais, in Fórum de Direito Urbano e Ambiental - FDUA, 43 (2009) $16-21$

- DIAS, EC, Tutela jurídica dos animais (Belo Horizonte 2000)

- FONDATION 30 MILLIONS D'AMIS. Statut juridique : les animaux reconnus définitivement comme des êtres sensibles dans le Code civil, 28 janv. 2015, in https://www.30millionsdamis.fr/actualites/article/8451-statut-juridique-les-animaux-reconnusdefinitivement-comme-des-etres-sensibles-dans-le-code/. [Last visited 20 March 2019]

- FRANCIONE, GL, Animals as persons (New York 2008)

- GOLDIM, JR, Histórico da Bioética, in HCPA, 2 (2006) 86-92, in https://www.ufrgs.br/bioetica/complex.pdf [last visited 10 March 2019]

- GORDILHO, HJS, Abolicionismo animal (Salvador 2009)

- HOSS, GM, Resenha/Review: Fritz Jahr and the foundations of global bioethics - the future of integrative bioethics, in Revista do Centro Universitário São Camilo, 2 (2012) 237-239, edit by Amir Muzur, Hans-Martin Sass

- JAHR, F., Bio-Ethic: eine umschau über die ethischen. Beziehungen des menschen zu tier und pflanze, in Kosmos Handweiser für Naturfreunde, 1 (1927) 2-4

- JONAS, H., O princípio responsabilidade: ensaio de uma ética para a civilização tecnológica (Rio de Janeiro 2006)

- KELSEN, H., Teoria geral do Direito e do Estado (São Paulo 1995)

- KUHN, TS, A estrutura das revoluções científicas (São Paulo 2013)

- LANZA, R., Biocentrismo, in Pensar Além, November 21, 2009, in http://pensaralem.wordpress.com/2013/11/21/biocentrismo-robert-lanza-2009/ [last visited 10 February 2019]

- LISBOA, RS, Teoria geral do Direito Civil (São Paulo 2010)

- LOURENÇO, DB, Direito dos Animais: fundamentação e novas perspectivas (Porto Alegre 2008)

- MACHADO, SM et al., Los animales y el Derecho (Madrid 1999)

- MANIFESTE, Pour une evolución du régime juridique de l'animal dans le code civil Reconnaissant sa nature d'être sensible, Mars 2018, in http://www.30millionsdamis.fr/fileadmin/user_upload/actu/10-2013/Manifeste.pdf [ last visited 12 February 2019]

- MEDEIROS, FLF, Direito dos animais (Porto Alegre 2013)

- MILARÉ, É., Direito do ambiente, in Revista dos Tribunais (2011) 119

- NAESS, A, The shalow and the deep, long-range ecology movement: a summary, in Inquiry, 16 (1973) 95-100

- PESSINI, L, As origens da bioética: do credo bioético de Potter ao imperativo bioético de Fritz Jahr, in Revista Bioética, 1 (2013) 9-19

- PESSINI, L., BARCHIFONTAINE, CP, Problemas atuais de bioética (São Paulo/Centro Universitário São Camilo 2007)

- PLANCK, M., Scientific autobiography and other papers (New York 1949)

- PRIMATT, H., A dissertation on the duty of mercy and sin of cruelty to brute animals, 1776, in Animal Rights History, in http://www.animalrightshistory.org/animal-rights-c16601785/enlightenment-p/pri-humphrey-primatt/1776-mercy-cruelty.htm [last visited 23 April 2019]

- REGAN, T., Jaulas Vazias (Porto Alegre 2006) 
- REGAN, T., The case for animal rights (Berkeley and Los Angeles 2004)

- RYDER, R., All beings that feel pain deserve human rights: equality of the species is the logical conclusion of post-Darwin morality, in The Guardian, Saturday 6 August (2000), in: http://www.theguardian.com/uk/2005/aug/06/animalwelfare [last visited 23 February 2019]

- SALLES, AA, Uma bioética e hipotética petição inicial: subsídios para a caracterização do animal como pessoa física não humana no Direito brasileiro, in BIZAWU, SK (Coord.), Direito dos Animais: desafios e perspectivas da proteção internacional, Arraes, Belo Horizonte (2015) 91-122

- SALT, H., Animals' Rights: Considered in Relation to Social Progress (Pennsylvania 1980)

- SCHWEITZER, A., The problem of peace, in HABERMAN, FW (Edit.), Nobel lectures: Peace 1951-1970, Elsevier, Amsterdam (1972) (speech of November 1954), in http://nobelprize.org [last visited 2 February 2019]

- SILVA, TTA, Animais em juízo (Salvador 2013)

- SILVA, TTA, Direito animal \& ensino jurídico (Salvador 2014)

- SINGER, P., Ética prática (São Paulo 2002)

- SINGER, P., Libertação animal (Porto Alegre 2004)

- STONE, C., Should trees have standing? Toward legal rights for natural objects, in Law Review, 45 (1972) 450-481

- UNESCO, Declaração Universal dos Direitos dos Animais, Bruxelas January 27, 1978, in Portal do Conselho Federal de Medicina Veterinária, in http://portal.cfmv.gov.br/uploads/direitos.pdf [last visited 14 February 2019]

- WISE, SM, Animal thing to animal person - Thoughts on time, place, and theories, in Animal Law, 5 (1999) 61-68

- WISE, SM, Lecture in I Congresso Mundial de Bioética e Direito Animal, Universidade Federal da Bahia (UFBA), Salvador, October 8 (2008) 